\title{
Low plasma concentrations of VIP and elevated levels of other neuropeptides during exacerbations of asthma
}

\author{
L.O. Cardell*, R. Uddman*, L. Edvinsson**
}

Low plasma concentrations of VIP and elevated levels of other neuropeptides during exacerbations of asthma. L.O. Cardell, R. Uddman, L. Edvinsson. CERS Journals Ltd 1994.

ABSTRACT: Neuropeptides in the lung occur in neurons, neuroendocrine and inflammatory cells. Their widespread distribution and physiological effects suggest that they may play important roles in asthma. We investigated whether, during an exacerbation of asthma, patients displayed changes in plasma levels of the neuropeptides vasoactive intestinal peptide (VIP), calcitonin gene-related peptide (CGRP), substance P (SP), and neuropeptide Y (NPY).

Venous blood from 25 adult patients attending the emergency ward with an exacerbation of asthma was sampled before and after treatment. Plasma levels of VIP-, SP-, CGRP- and NPY-like immunoreactivity (-LI) were determined by immunoassay, and the results obtained were compared with findings in 21 healthy controls.

The mean plasma levels of VIP-LI were lower in patients $\left(3.4 \pm 0.4 \mathrm{pmol} \cdot l^{-1}\right)$ than in controls $\left(10.4 \pm 0.7 \mathrm{pmol} \cdot l^{-1}\right)$, whereas the levels of CGRP-LI $\left(43.7 \pm 3.4 \mathrm{pmol} \cdot l^{-1}\right)$, SP-LI $\left(4.6 \pm 0.4 \mathrm{pmol} \cdot l^{-1}\right)$ and NPY-LI levels $\left(159 \pm 6 \mathrm{pmol} \cdot l^{-1}\right)$ were higher in patients than in controls $\left(21.1 \pm 3.4 ; 2.2 \pm 0.2\right.$ and $105 \pm 8 \mathrm{pmol} \cdot l^{-1}$, respectively). A relationship was seen between the reversibility of obstruction, expressed as improvement of peak expiratory flow upon treatment, and the neuropeptide levels, such that lower VIP. LI levels and higher CGRP-LI levels correlated with less reversibility.

Plasma levels of neuropeptides, VIP-LI and CGRP-LI in particular, may therefore be employed as predictors of responsiveness to bronchodilatory therapy. Eur Respir J., 1994, 7, 2169-2173.
*Dept of Otorhinolaryngology, Malmö General Hospital, Malmö Sweden. **Dept of Internal Medicine, University of Lund, Lund, Sweden.

Correspondence: L.O. Cardell

Dept of Otorhinolaryngology

Malmö General Hospital

S-21401 Malmö

Sweden

Keywords: Calcitonin gene-related peptide neuropeptide $\mathrm{Y}$

plasma levels

radio-immunoassay

substance $\mathrm{P}$

vasoactive intestinal peptide

Received: February 241994

Accepted after revision July 81994

This work was supported by grants from the Swedish Medical Research Council (project No. 5958), the Swedish Heart Lung Foundation, the Swedish Society of Medicine, the Swedish Society of Medicine Research, Swedish Association for Allergology and University of Lund.
Several studies have established that numerous neuropeptides are produced and released from the lung $[1,2]$. Nerve fibres containing vasoactive intestinal polypeptide (VIP), calcitonin gene-related peptide (CGRP), substance $\mathrm{P}$ (SP) and neuropeptide Y (NPY) are seen around pulmonary blood vessels and close to small bronchioles [3]. Endocrine cells, solitary as well as clustered, can be seen in bronchi and bronchioles [4]. In addition, SP and VIP have been identified in various inflammatory cells, such as eosinophils, mast cells and leucocytes [5].

Inhibitory nonadrenergic, noncholinergic (i-NANC) nerves constitute the main bronchodilator pathway in human airways [2]. Animal studies suggest that VIP and closely related peptides [6], together with nitric oxide (NO) [7], may act as neurotransmitters of this system. The co-localization of VIP with acetylcholine [8] suggests that VIP may act as a functional "brake" upon cholinergic bronchoconstriction. Hence, if VIP is absent or degraded by peptidases released from inflammatory cells, this could lead to unopposed cholinergic reflex bronchoconstriction.
The concept of a rapid breakdown of VIP in asthmatic airways, as a result of various enzymes released from mast cells and epithelium, represents one facet of the complex interaction between inflammation and neural control. Another aspect of this connection is represented by the neurogenic inflammation [9]. Damage to airway epithelium exposes sensory nerve endings which, when activated by inflammatory mediators, leads to a release of SP and CGRP. Since the effects of these peptides mimic many of the features of asthma, it is tempting to speculate that they may be involved in its pathogenesis.

NPY is co-localized with norepinephrine in pulmonary adrenergic nerves [10], but has also been found to coexist with a subpopulation of VIP- and acetylcholineesterase-positive nerve cell bodies in cranial and cervical parasympathetic ganglia $[11,12]$. Since airway smooth muscle in humans has a scarce supply of sympathetic nerves, a substantial portion of the NPY-like material found could be of cholinergic origin.

In the present study, we used radio-immunoassays in order to elucidate the roles of VIP, CGRP, SP and NPY in the acute exacerbation of asthma in adults. 


\section{Material and methods}

\section{Patients}

The study was performed during one week, and informed consent was obtained from all participants. Twenty five patients (14 females and 11 males) with a history of acute asthma were recruited when they presented to the internal medicine emergency ward at Malmö General Hospital with an acute exacerbation of asthma. They were clinically evaluated by an experienced resident/ consultant and patients with significant infection, emphysema and/or other cardiopulmonary disease were excluded. Two patients were habitual smokers. All patients were on treatment with theophylline and/or $\beta_{2}$-agonist given orally and/or as inhalation. All had used their bronchodilators prior to the arrival in the emergency room, but no patient used oral steroids at the time of investigation. The patients were aged 28-80 yrs (61 \pm 4 yrs (mean \pm SEM), $n=25)$, and the control group consisted of healthy volunteers aged $20-70$ yrs $(n=21)$ (table 1) with no history of cardiopulmonary disease. The controls were comparable in terms of age and sex. No correlations between neuropeptide levels and age were found in the present material. The peak expiratory flow (PEF) was recorded as the best out of three blows [13].

Venous samples for determination of neuropeptides (VIP- CGRP-, SP- and NPY like immunoactivity (LI)) were taken at the arrival after 5-15 min rest, but before any treatment was started. For nine patients the first set of venous samples was taken between $7.30-12.00 \mathrm{~h}$, for 11 patients between $12.00-16.30 \mathrm{~h}$, and for the remaining patients between 16.30-07.30h. Venous samples from control patients were sampled between $07.30-16.30 \mathrm{~h}$. There was no relationship between the peptide levels obtained and the time of day at which these samples were taken.

All patients received the same standardized antiobstructive treatment with a combination of theophylline (Teofyllamin ${ }^{\circledR}$ 10-20 mg), a glucocorticoid (Betapred ${ }^{\circledR}$ 4-8 mg) given intravenously, and a short-acting $\beta_{2}$-agonist (Bricanyl ${ }^{\circledR} 0.25-0.50 \mathrm{mg}$ ) given subcutaneously. Additional treatment with a combination of salbutamol (Ventolin ${ }^{\circledR} 2.5-50 \mathrm{mg}$ ), a $\beta_{2}$-adrenoceptor stimulant, and ipratropium bromide (Atrovent ${ }^{\circledR} 0.25 \mathrm{mg}$ ), a nonselective muscarinic receptor antagonist, administrated via a nebulizer, was also given. Twenty three of the patients recovered and were able to leave the hospital within a few hours (110 $\pm 13 \mathrm{~min})$. Two patients required admission to the department of internal medicine for continued treatment over 18 and $24 \mathrm{~h}$, respectively.

A new set of PEF measurements was obtained and new venous samples were taken just before the patients were to leave the hospital. Visual analogue scale (VAS), a vertical line with two anchor points, one at each extreme, was used to evaluate the degree of discomfort evoked by breathing [14]. The scale was labelled "no respiratory discomfort" at the bottom and "worst imaginable respiratory discomfort" at the top.

\section{Radio-immunoassay}

For immunoassay of peptides, blood samples were collected in chilled tubes containing ethylenediamine tetra-acetic acid (EDTA) $\left(1 \mathrm{mg} \cdot \mathrm{ml}^{-1}\right)$, immediately transported to the laboratory on ice and centrifuged at $+4^{\circ} \mathrm{C}$, $2,000 \times \mathrm{g}$ for $10 \mathrm{~min}$. The plasma was collected and frozen at $-20^{\circ} \mathrm{C}$ for later analysis. The results represent peptide-like immunoreactivity. All plasma samples were analysed in duplicate and corrected for nonspecific binding. For simplicity, data are referred to as plasma peptide levels.

Immunoreactive VIP was determined with a rabbit antiserum (code 7852, Euro-diagnostics, Malmö, Sweden). The antiserum was used at a dilution of 1:60,000 and did not cross-react with peptide histidine isoleucine, secretin or glucagon [15]. The detection limit was 5 $\mathrm{pmol} \cdot l^{-1}$. The interassay and intra-assay variations were 8.5 and $<5 \%$, respectively.

Immunoreactive SP was quantified using a rabbit antiserum SP-2 at a final dilution of 1:50,000 and ${ }^{131} \mathrm{I}-\left(\mathrm{Tyr}^{8}\right)$ $\mathrm{SP}$ as tracer. The detection limit was $1.0 \mathrm{pmol} \cdot l^{-1}$. The SP-2 antiserum does not detect any known tachykinin other than SP [16]. The interassay and intra-assay variations were 7.7 and $<5 \%$, respectively.

Immunoreactive CGRP was quantified using a rabbit antiserum (R-8429) raised against synthetic rat CGRP, conjugated to bovine serum albumin and used at a final dilution of 1:37,000. Iodinated CGRP was purified by high performance liquid chromatography (HPLC). This enabled measurement of CGRP with a sensitivity of 10 pmol. $l^{-1}$ without cross-reaction with calcitonin, katacalcin or calcitonin $\mathrm{C}$-terminal adjacent peptide up to $300 \mathrm{nM}$. The interassay and intra-assay variations were 12.1 and $<5 \%$, respectively [17].

The plasma levels of NPY immunoreactivity were determined as previously described [18]. The antiserum used was raised against synthetic porcine NPY and conjugated to bovine serum albumin with carbodiimide. ${ }^{125}$ I-NPY, used as a tracer, was purified by HPLC. The antiserum cross-reacted with peptide YY (PYY) to $33 \%$ but not with C-terminal fragments of NPY or PYY (NPY 13-36, PYY 13-36), or with bovine pancreatic polypeptide, gastrin inhibiting peptide, peptide histidine isoleucine, VIP or secretin. The detection limit was $25 \mathrm{pmol} \cdot \mathrm{l}^{-1}$. The interassay and intra-assay variations were 7.0 and $<5 \%$, respectively. The contribution of PYY to the NPY-LI level was estimated to be about $10 \%$ [19].

\section{Statistics}

The results are presented as mean \pm SEM. Statistical differences between means were tested by analysis of variance (ANOVA) [20]. Regression lines are plotted together with a scatter diagram of the raw data where $r$ represents correlation coefficients and SD the standard deviation of the slope. Statistical significance was assumed at a p-value of $<0.05$. 


\section{Results}

The VIP-LI plasma levels of 25 patients during an acute exacerbation of asthma were significantly lower than in healthy controls (patients $3.4 \pm 0.4 \mathrm{pmol} \cdot l^{-1}$, controls $\left.10.4 \pm 0.7 \mathrm{pmol} \cdot l^{-1}, \mathrm{p}<0.05\right)$, whereas the CGRPLI and SP-LI levels for the same patients were significantly higher than in controls (SP-LI: patients $4.6 \pm 0.4 \mathrm{pmol} \cdot l^{-1}$, controls $2.2 \pm 0.2 \mathrm{pmol} \cdot l^{-1}, \mathrm{p}<0.02$; CGRP-LI: patients $43.7 \pm 3.4 \mathrm{pmol} \cdot l^{-1}$, controls $21.1 \pm 3.4 \mathrm{pmol} \cdot l^{-1} \mathrm{p}<0.05$;). There were also significantly elevated NPY-LI levels (patients $159 \pm 6 \mathrm{pmol} \cdot l^{-1}$, controls $105 \pm 8 \mathrm{pmol} \cdot l^{-1}, \mathrm{p}<0.05$ ). Significant differences were not found between the plasma levels obtained prior to treatment and the levels registered when the patients had recovered and were about to leave the hospital (table 1). Neither did the two patients who were hospitalized for continued treatment differ in their plasma levels from the 23 patients who left the hospital within a few hours.

The recorded PEF improvement as a result of the antiobstructive treatment given varied between the individual patients. When the PEF improvement for each patient was plotted in a scatter diagram together with the individual neuropeptide levels (VIP-, CGRP-, SP- and NPYLI), regression analyses indicated a relationship between the reversibility of obstruction and changes in the

a)

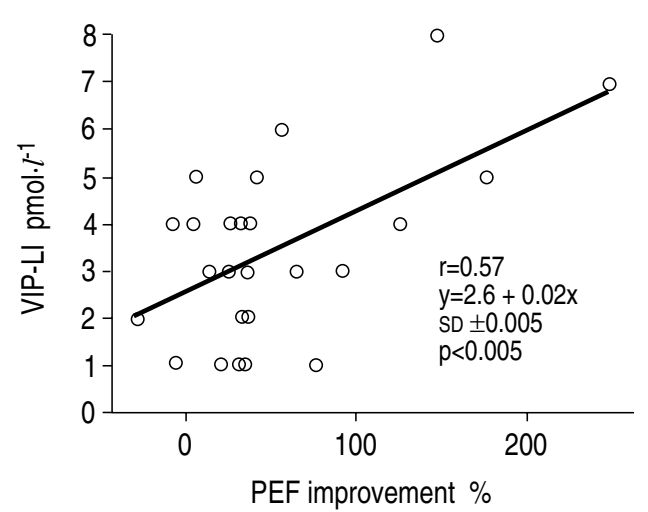

c)

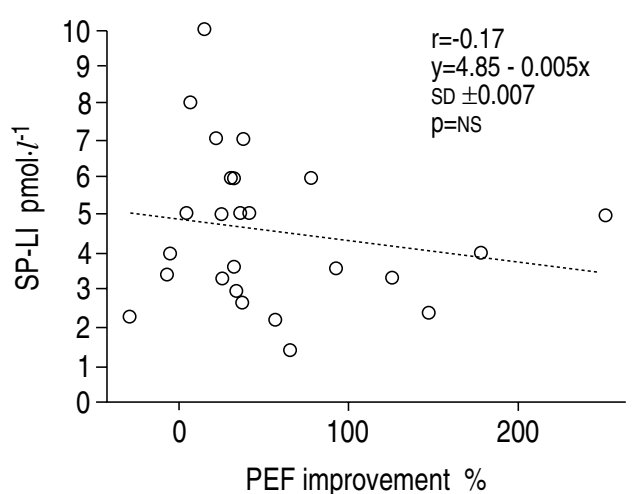

Table 1. - VIP-, SP-, CGRP-, and NPY-LI plasma levels in asthmatic patients before and after the treatment of an acute exacerbation of asthma compared to healthy volunteers

\begin{tabular}{lccc}
\hline & Controls & \multicolumn{2}{c}{ Asthmatics } \\
\cline { 3 - 4 } & & $\begin{array}{c}\text { Pre- } \\
\text { treatment }\end{array}$ & $\begin{array}{c}\text { Post- } \\
\text { treatment }\end{array}$ \\
\hline $\mathrm{n}$ & $16 \dagger, 20^{+}$ & 25 & 25 \\
PEF $l \cdot \mathrm{min}^{-1}$ & - & $171 \pm 16$ & $256 \pm 29$ \\
VIP-LI pmol $\cdot l^{-1}$ & $10.4 \pm 0.7^{*}$ & $3.4 \pm 0.4$ & $3.1 \pm 0.5$ \\
SP-LI pmol $l l^{-1}$ & $2.2 \pm 0.2^{*}$ & $4.6 \pm 0.4$ & $4.7 \pm 0.5$ \\
CGRP-LI pmol $\cdot l^{-1}$ & $21.1 \pm 3.4^{*}$ & $43.7 \pm 3.4$ & $44.5 \pm 3.6$ \\
NPY-LI pmol $\cdot l^{-1}$ & $105 \pm 8^{*}$ & $159 \pm 6$ & $150 \pm 4$ \\
\hline
\end{tabular}

PEF: peak expiratory flow; VIP-LI: vasoactive intestinal peptidelike immunoreactivity; SP-LI: substance P-like immunoreactivity; CGRP-LI: calcitonin gene-related peptide-like immunoreactivity; NPY-LI: neuropeptide Y-like immunoreactivity. $\dagger$ : VIP-LI and SP-LI controls, age $53 \pm 4$ yrs; +:CGRP-LI controls and NPYLI controls, age $57 \pm 5$ yrs. The values represent the mean \pm SEM. $*: p<0.05$ controls $v s$ asthmatics, ANOVA analysis of variance.

VIP-LI and CGRP-LI levels, such that lower VIP-LI levels and higher CGRP-LI levels correlated with less reversibility (fig. 1). The self-rated registration of the degree of respiratory discomfort on the VAS indicated that all patients, including those in whom no improvement of the PEF values were seen, experienced a subjective
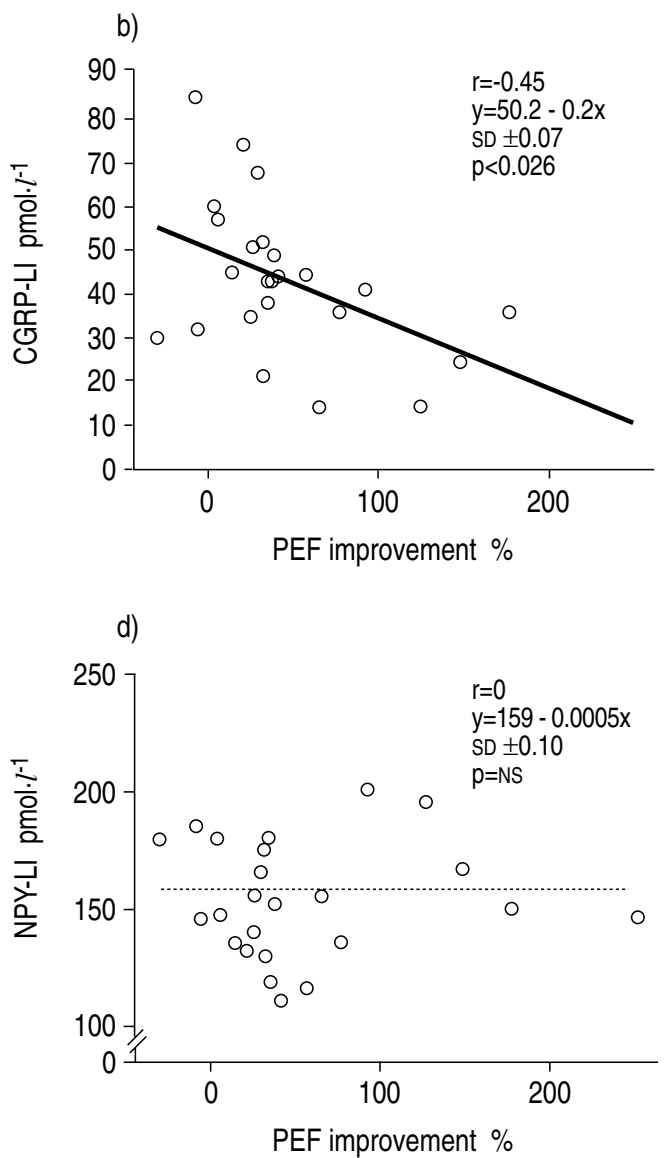

Fig. 1. - a) VIP-LI; b) CGRP-LI; c) SP-LI; and d) NPY-LI plasma levels during acute exacerbation of asthma in relation to reversibility of obstruction expressed as improvement of peak expiratory flow upon given treatment (PEF improvement). r: correlation coefficient; $y=a+b x$ : regression analysis; SD: standard deviation of the slope (b); p:predicts the hypothesis of a zero slope, i.e. of no relationship between PEF improvement and peptide plasma levels. VIP-LI: vasoactive intestinal peptide-like immunoreactivity; CGRP-LI: calcitonin gene-related peptide-like immunoreactivity; SP-LI: substance P-like immunoreactivity; NPY-LI: neuropeptide Y-like immunoreactivity. 
a)

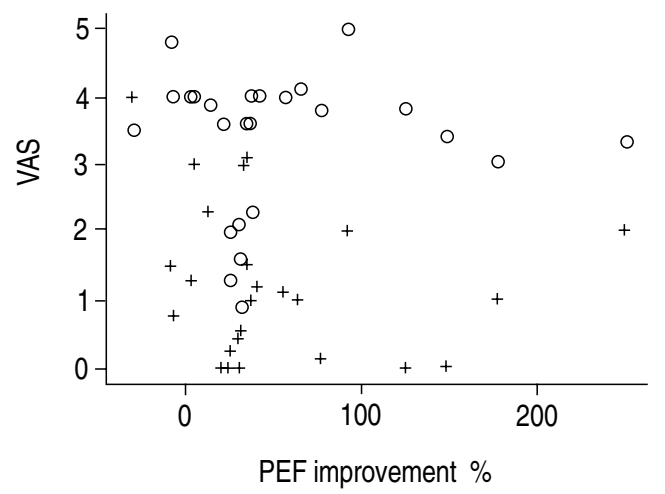

b)

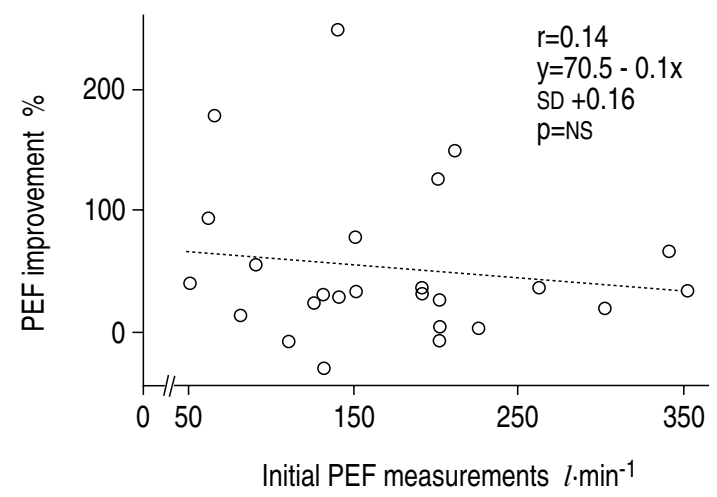

Fig. 2. - a) Self-rated registration of the degree of respiratory discomfort on the visual analogue score (VAS) (0=no respiratory discomfort; $5=$ worst imaginable respiratory discomfort) before $(\mathrm{o})$ and after $(+)$ antiobstructive treatment. All patients, including those in whom no improvement of the PEF values were seen, experienced a subjective improvement as a result of the treatment received. b) Reversibility of the airway obstruction expressed as PEF improvement (\%) upon treatment in relation to the first set of PEF measurements. No correlations between the PEF improvement (\%) obtained and the initial PEF level for the individual patient can be seen. PEF: peak expiratory flow.

improvement as a result of the treatment (fig. 2a). However, there was no correlation between the improvement obtained and the initial PEF level for the individual patient ( $\mathrm{r}=0.14 ; \mathrm{y}=70.5-0.1 \mathrm{x} ; \mathrm{SD}+0.16 ; \mathrm{p}=0.51$ ) (fig. $2 \mathrm{~b})$.

\section{Discussion}

In the present study, low levels of circulating VIP-LI and high levels of circulating CGRP-, SP- and NPY-LI were seen during acute exacerbation of asthma as compared to controls. These levels did not change under therapy. The time interval between pre- and post-treatment was short, only about $2 \mathrm{~h}$, and the changes obtained may represent the effects of more slowly acting mechanisms.

Shedding of the epithelium may expose sensory nerve endings which can be triggered or sensitized by irritants or mediators. This activation causes antidromic release of neuropeptides, such as SP, NKA and CGRP, resulting in local vasodilation and plasma protein extravasation. Antidromic stimulation of sensory nerve endings may also cause bronchial smooth muscle contraction, glandular secretion and facilitation of parasympathetic fibre activity [2]. It has been proposed, but not shown, that some of the symptoms of asthma may result from proinflammatory effects mediated by afferent nerves, leading to higher circulating levels of SP and CGRP. Degradation of neuropeptides is another mechanism affecting the physiological levels of neuropeptides. Neutral endopeptidase (NEP), angiotensin converting enzyme, mast cell tryptase and chymase are examples of peptidedegrading enzymes found in the airways. These enzymes may be directly responsible for regulating the actions of several peptides, such as bradykinin, VIP and tachykinins [21,22]. NEP is produced by epithelial cells and is responsible for the continuous degradation of released tachykinins. Removal or damage to the epithelium, as caused by irritants or respiratory viral infections, will reduce its activity, which may lead to enhanced effects of tachykinins. Together with the release of free radicals from other types of inflammatory cells, tryptase may reduce the dilatory actions of VIP and NO, leading to unopposed cholinergic bronchoconstriction [23, 24].

The suggestion that VIP may be deficient in patients with bronchial asthma was first proposed by MATSUZAKI et al. [25]. In 1989, OlleRENSHAW et al. [26] demonstrated the complete absence of VIP-immunoreactive nerves in postmortem preparations of lungs from five subjects with asthma. They suggested that asthma was associated with loss of VIP containing nerves. The cause of these findings were subjected to debate, and further investigations by the use of radio-immunoassay was proposed [27, 28].

The concept of neurogenic inflammation in the airways and its involvement in human asthma is debated [29]. The present findings of increased plasma levels of SP-LI and CGRP-LI in asthmatic patients support such a concept. Further support comes from recent findings of increased amounts of SP-immunoreactive nerve fibres in asthmatic airways and elevated SP-LI levels in bronchial lavage fluids from asthmatic patients [30,31]. The present results also indicate a relationship between the reversibility of obstruction and raised levels of CGRP-LI. High circulating CGRP-LI levels seem to correlate with less reversibility.

Recent studies have shown that NPY may modulate cholinergic neurotransmission in the airways [32], and reduce bronchial blood flow [33]. An increase of the NPY-LI plasma levels in elderly asthmatics has been described [34], and these results are well in line with the present findings. Since there were no differences between the NPY-LI levels obtained before and after treatment, the elevated levels of NPY-LI are not directly correlated with the sympathoadrenal stress caused by the acute exacerbation but rather related to more long term-changes.

The present study indicates a relationship between acute exacerbations of asthma and low plasma concentrations of VIP and elevated levels of CGRP, SP and NPY. Furthermore, there may be a relationship between the responsiveness to bronchodilator therapy and the plasma levels of VIP and CGRP. However, the observed changes are probably secondary phenomena and they are unlikely to be the fundamental cause of the abnormality in asthma. 


\section{References}

1 Uddman R, Sundler F. Neuropeptides in the airways: a review. Am Rev Respir Dis 1987; 136: S3-8.

2. Barnes PJ. Neural mechanism in asthma. In: Barnes PJ, eds. Asthma. Churchill Livingstone, 1992; 48: pp. 149-168.

3. Luts A, Uddman R, Alm P, Basterra J, Sundler F. Peptidecontaining nerve fibers in human airways: distribution and co-existence pattern. Int Arch Allergy Appl Immunol 1993; 101: 52-60.

4. Gosney JR, Sissons MCJ, Allibone RO, Blackey AF. Pulmonary endocrine cells in chronic bronchitis and emphysema. J Pathol 1989; 157: 127-133.

5. Casale TB. Neuropeptides and the lung. J Allergy Clin Immunol 1991; 88: 1-14.

6. Palmer JB, Cuss FM, Barnes PJ. VIP and PHM and their role in nonadrenergic inhibitory responses in isolated human airways. J Appl Physiol 1986; 61: 1322-1328.

7. Belvisi MG, Stretton D, Barnes PJ. Nitric oxide as an endogenous modulator of cholinergic neurotransmission in guinea-pig airways. Eur J Pharmacol 1991; 198: 219-221.

8. Lundberg JM, Hökfelt T, Schultzberg M, Uvnäs-Wallensten K, Köhler C, Saria A. Occurrence of vasoactive intestinal polypeptide (VIP)-like immunoreactivity in certain cholinergic neurons in the rat: evidence from combined immunohistochemical and acetylcholinesterase staining. Neuroscience 1979; 4: 1539-1559.

9. Barnes PJ. Asthma as an axon reflex. Lancet 1986; i: 242-245.

10. Sundler F, Håkanson R, Ekblad E, Uddman R, Wahlestedt C. Neuropeptide $\mathrm{Y}$ in the peripheral adrenergic and enteric nervous systems. In: Bourne GH, eds. International Review of Cytology. Academic Press Inc. 1986; 102: 243-269.

11. Grunditz T, Ekman R, Håkanson R, Sundler F, Uddman R. Neuropeptide Y and vasoactive intestinal peptide coexist in rat thyroid nerve fibers emanating from the thyroid ganglion. Regul Pept 1988; 23: 193-203.

12. Leblanc GG, Trimmer BA, Landis SC. Neuropeptide Ylike immunoreactivity in rat cranial parasympathetic neurons: coexistence with vasoactive intestinal peptide and choline acetyltransferase. Proc Natl Acad Sci USA 1987; 84: 3511-3515.

13. Wright BM, McKerrow CB. Maximum forced expiratory flow rate as a measure of ventilatory capacity. $\mathrm{Br} \mathrm{Med}$ $J$ 1959; 2: 1041-1047.

14. Mador MJ, Kufel TJ. Reproducibility of visual analog scale measurements of dyspnea in patients with chronic obstructive pulmonary disease. Am Rev Respir Dis 1992; 146: 82-87.

15. Helm G, Ekman R, Rydhström H, Sjöberg N-O, Walles B. Changes in oviductal VIP content induced by sex steroids and inhibitory effect of VIP on spontaneously oviductal contractility. Acta Physiol Scand 1985; 125: 219-224.

16. Brodin E, Lindefors N, Theodorsson-Norheim E, et al. Tachykinis in rat central nervous system: distribution, molecular forms, release and effects of chronic treatment with antidepressant drugs. In: Håkanson $\mathrm{R}$, Sundler F, eds. Tachykinin Antagonists. Amsterdam, Elsevier Science Publishers BV 1985; pp. 15-27.

17. Grunditz T, Ekman R, Håkanson R, Rerup C, Sundler F, Uddman R. Calcitonin gene-related peptide in thyroid nerve fibers and C-cells: effects of thyroid hormone secretion and response to hypercalcemia. Endocrinology 1986; 119; 313-323.

18. Widerlöv E, Heilig M, Ekman R, Wahlestedt C. Possible relationship between neuropeptide Y (NPY) and major depression: evidence from human and animal studies. Nord Psychiatr Tidskr 1988; 42: 131-137.

19. Edvinsson L, Ekman R, Thulin T. Increased plasma levels of neuropeptide Y-like immunoreactivity and catechol-amines in severe hypertension remain after treatment to normotension in man. Regul Pept 1991; 32: 279-287.

20. Wallenstein S, Zucker CL, Fleiss J. Some statistical methods useful in circulation research. Circ Res 1980; 47: 1-9.

21. Burmet NW. Release and breakdown: postsecretory metabolism of peptides. Am Rev Respir Dis 1987; 136: S27-34.

22. Hachisu M, Hiranuma T, Tani S, Iizuka T. Enzymatic degradation of helodermin and vasoactive intestinal polypeptide. J Pharmacobio Dyn 1991; 14: 126-131.

23. Caughey GH, Leidig F, Viro NF, Nadel JA. Substance $\mathrm{P}$ and vasoactive intestinal peptide degradation by mast cell tryptase and chymase. J Pharmacol Exp Ther 1988; 244: 133-137.

24. Nadel JA. Decreased neutral endopeptidases: possible role in inflammatory diseases of airways. Lung 1990; 168: S123-127.

25. Matsuzaki Y, Hamasaki Y, Said SI. Vasoactive intestinal polypeptide: a possible transmitter of nonadrenergic relaxation of guinea-pig airways. Science 1980; 210: 1252-1253.

26. Ollerenshaw S, Jarvis D, Woolcock A, Sullivan C, Scheibner T. Absence of immunoreactive vasoactive intestinal polypeptide in tissue from the lungs of patients with asthma. N Engl J Med 1989; 320: 1244-1248.

27. Barnes PJ. Vasoactive intestinal peptide and asthma. N Engl J Med 1989; 321: 1128-1129.

28. Said SI. Vasoactive intestinal polypeptide and asthma. N Engl J Med 1989; 320: 1271-1273.

29. Lundberg JM, Saria A, Lundblad L, et al. Bioactive peptides in capsaicin-sensitive C-fibers of airways: functional and pathophysiological implications. In: Kaliner MA, Barnes PJ, eds. The airways: Neural Control in Health and Disease. New York, Marcel Dekker, 1987; pp. 417-445.

30. Ollerenshaw S, Jarvis D, Sullivan C, Woolcock A. Substance $\mathrm{P}$ immunoreactive nerves in airways from asthmatics and nonasthmatics. Eur Respir $J$ 1991; 4: 673-682.

31. Nieber K, Baumgarten CR, Rathsack R, Furkert J, Oehme $P$, Kunkel G. Substance $P$ and $\beta$-endorphin-like immunoreactivity in lavage fluids of subjects with and without allergic asthma. J Allergy Clin Immunol 1992; 90: 646-652.

32. Stretton D, Barnes PJ. Modulation of cholinergic neurotransmission in guinea-pig trachea by neuropeptide Y. Br J Pharmacol 1988; 93: 672-678.

33. Salonen RO, Webber SE, Widdicombe JG. Effects of neuropeptides and capsaicin on canine tracheal vasculature in vivo. Br J Pharmacol 1988; 95: 1265-1270.

34. Dahlöf C, Dahlöf P, Lundberg JM, Strömbom U. Elevated plasma concentration of neuropeptide $\mathrm{Y}$ and low levels of circulating adrenaline in elderly asthmatics during rest and acute severe asthma. Pulm Pharmacol 1988; 1: 3-6. 